ORIGINAL RESEARCH ARTICLE

\title{
Maternal and Child Health Services in the Context of the Ebola Virus Disease: Health Care Workers' Knowledge, Attitudes and Practices in Rural Guinea
}

\author{
Alexandre Delamou ${ }^{1,2 *}$, Sidikiba Sidibé ${ }^{1,2}$, Alison Marie El Ayadi ${ }^{3}$, Bienvenu Salim Camara ${ }^{2}$, \\ Thérèse Delvaux ${ }^{4}$, Bettina Utz', Abdoulaye II Toure ${ }^{4}$, Sah D. Sandouno ${ }^{1}$, Alioune Camaral, \\ Abdoul Habib Beavogui ${ }^{2}$, Asm Shahabuddin ${ }^{4}$, Karen Van der Veken ${ }^{4}$, Bouchra Assarag ${ }^{5}, J_{\text {Juko }}$ \\ Okumura $^{6}$ and Vincent De Brouwere ${ }^{4}$
}

Department of Public Health, Faculty of Medicine, University of Conakry, Guinea ${ }^{1}$; Centre de formation et de recherche en santé rurale de Maferinyah, Forécariah, Guinea ${ }^{2}$; Bixby Centre for Global Reproductive Health, University of California, San Francisco, USA ${ }^{3}$; Women and Child Health Research Centre, Institute of Tropical Medicine, Antwerp, Belgium ${ }^{4}$; Ecole nationale de santé publique, Rabat, Morocco ${ }^{5}$; Institute of Tropical Medicine and Global Health, Nagasaki University, Nagasaki, Japan ${ }^{6}$

*For Correspondence: Email: adelamou@gmail.com, Phone: +224 624877139

\begin{abstract}
The objective of this study was to document maternal and child health care workers' knowledge, attitudes and practices on service delivery before, during and after the 2014 EVD outbreak in rural Guinea. We conducted a descriptive cross-sectional study in ten health districts between October and December 2015, using a standardized self-administered questionnaire. Overall 299 CHWs (94\% response rate) participated in the study, including nurses/health technicians (49\%), midwives (23\%), managers (16\%) and physicians (12\%). Prior to the EVD outbreak, $87 \%$ of CHWs directly engaged in managing febrile cases within the facility, while the majority (89\% and 63\%) referred such cases to another facility and/or EVD treatment centre during and after the EVD outbreak, respectively. Compared to the period before the EVD outbreak when approximately half of CHWs (49\%) reported systematically measuring body temperature prior to providing any care to patients, most CHWs reported doing so during (98\%) and after the EVD outbreak (88\%). The main challenges encountered were the lack of capacity to screen for EVD cases within the facility $(39 \%)$ and the lack of relevant equipment $(10 \%)$. The majority $(91 \%)$ of HCWs reported a decrease in the use of services during the EVD outbreak while an increase was reported by $72 \%$ of respondents in the period following the EVD outbreak. Infection prevention and control measures established during the EVD outbreak have substantially improved selfreported provider practices for maternal and child health services in rural Guinea. However, more efforts are needed to maintain and sustain the gain achieved. (Afr J Reprod Health 2017; 21[1]: 104-113).
\end{abstract}

Key words: Maternal and child health, practices, Ebola, Guinea

\section{Résumé}

L'objectif de cette étude était de documenter les connaissances, les attitudes et les pratiques du personnel de la santé maternelle et infantile sur la prestation des services avant, pendant et après l'épidémie de MVE de 2014 en Guinée rurale. Nous avons effectué une étude descriptive transversale dans dix districts sanitaires entre octobre et décembre 2015, à l'aide d'un questionnaire standardisé auto-administré. Dans l'ensemble, 299 membres du personnel de la santé (taux de réponse de 94\%) ont participé à l'étude, y compris les infirmières et les techniciens en santé (49\%), les sages-femmes (23\%), les gestionnaires (16\%) et les médecins (12\%). Avant la survenue de la MVE, $87 \%$ du personnel de la santé était directement impliqués dans le traitement des cas fébriles dans l'établissement, tandis que la majorité (89\% et $63 \%)$ ont envoyé tels cas chez les spécialistes dans un autre établissement et /ou dans un centre de traitement de la MVE pendant et après l'épidémie de la MVE respectivement. Par rapport à la période précédant l'éclosion de la MVE, environ la moitié du personnel de la santé (49\%) ont signalé avoir mesuré systématiquement la température corporelle avant de dispenser des soins aux patientes. La plupart du personnel de la santé ont déclaré l'avoir fait pendant (98\%) et après l'éclosion de la MVE (88\%). Les principaux défis rencontrés ont été le manque de capacité de dépister les cas de la MVE au sein de l'établissement (39\%) et le manque d'équipement pertinent (10\%). La majorité (91\%) du personnel de la santé ont signalé une diminution de l'utilisation des services au cours de l'épidémie de la MVE alors qu'une augmentation était signalée par 72\% des interviewées au cours de la période suivant l'éclosion de la MVE. Les mesures de prévention et de lutte contre les infections mises en place lors de l'épidémie de la MVE ont considérablement amélioré les pratiques des prestataires auto déclarés pour les services de santé maternelle et infantile en Guinée rurale. Cependant, des efforts supplémentaires sont nécessaires pour maintenir et soutenir le bénéfice obtenu. (Afr J Reprod Health 2017; 21 [1]: 104-113).

Mots-clés: La santé maternelle et infantile, de pratiques, de l'Ebola, la Guinée 


\section{Introduction}

The 2014 Ebola virus disease (EVD) outbreak started in Guinea and spread to Sierra Leone and Liberia, rapidly becoming a global public health emergency ${ }^{1,2}$. A total of 3,804 EVD cases were reported in Guinea as of February 14, 2016, including 211 cases among healthcare workers (CHWs). The case-fatality rates were $67 \%$ and $55 \%$ in the general population and in CHWs, respectively. ${ }^{3}$. CHWs are at higher risk of contracting Ebola than the general population because of their direct involvement in case management ${ }^{4}$, particularly those providing obstetric care ${ }^{5}$. In combination with this increased risk, inadequate training and insufficient availability of personal protective equipment has led to desertion of services by CHWs due to fear of contracting infection ${ }^{6}$. In Conakry, Touré et al. ${ }^{4}$ found that nearly $18 \%$ of CHWs reported no systematic screening for EVD, with the majority $(96.6 \%)$ not even routinely using gloves ${ }^{4}$. This raised the question of whether the educational efforts themselves were inadequate or whether CHWs were not implementing the infection prevention and control standards learned.

Therefore, understanding the EVD knowledge of $\mathrm{CHWs}$, their experiences providing routine and emergency health care, and their attitudes and practices during the EVD response is important for the prevention and management of any similar future outbreak ${ }^{10}$. This is particularly true for $\mathrm{CHWs}$ providing maternal and child health services as women and children were more exposed to and most affected by the EVD outbreak $^{11}$. Further emphasis must also be placed on understanding and overcoming the challenges specific to rural providers, as most EVD cases occurred in rural areas ${ }^{3}$. In Guinea, $55.2 \%$ of CHWs nationwide (doctors, midwives and nurses) work in the region of Conakry where only $40 \%$ of the country's population lives ${ }^{7,9}$, highlighting an insufficient health workforce in areas critical to stemming the EVD outbreak.

In this study, we sought to understand rural CHWs' knowledge, attitudes and comparative practices of maternal and child health service delivery before, during, and after the Guinean EVD outbreak.

\section{Methods}

\section{Study design}

We conducted a descriptive cross-sectional study. Data collection took place from October to December, 2015.

\section{Study setting}

Guinea is located in West Africa and was among the three countries most affected by the 2014-2015 Ebola epidemic ${ }^{2}$. As of 2012, the maternal mortality ratio was estimated at 724 per 100,000 live births and the infant mortality rate at 65 per 1,000 live births $^{8}$. Antenatal care (ANC) coverage is high for at least one visit (85\%) while complete vaccination coverage among children aged 12-23 months $(37 \%)$ and postnatal care $(43 \%)$ are low $^{8}$.

The study was conducted in public health facilities within ten rural health districts located in the Forest and Lower regions of Guinea. The two regions account for $40 \%$ of the country's population and were the most EVD-affected regions with 2433 reported EVD cases (64\% of the nationwide caseload) $)^{3,7}$. The following districts were included: Kissidougou, Guéckédou, Macenta, Nzérékoré and Lola (Forest Guinea), Dubreka, Coyah, Forecariah, Telemele and Kindia (Lower Guinea). The public health infrastructure across the two regions includes two regional and thirteen district hospitals, 172 health centers and 541 health posts.

\section{Study population and selection process}

The study population included all health care workers (CHWs) involved in the provision of maternal and child health care services (care providers and managers) in the study health districts. First, the five most EVD-affected health districts in each of the two regions were identified based on the national EVD epidemiological situation report ${ }^{3}$. Second, in the selected districts, all the public health centers and maternities within the two most EVD incident sub-districts/urban communes were included in the study (in total ten maternities and twenty health centers). The study team individually approached all maternal and child health care workers in these facilities 
$(n=318)$ to request their participation in the study. Informed consent was sought in a private place and was administered into French. Of the 318 CHWs approached, 299 (94.2\%) from ten districts consented to participate and responded to the study questionnaire.

\section{Data collection and variables}

We collected data using a standardized selfadministered questionnaire that was previously pre-tested among healthcare providers in a maternity hospital in Conakry. Questions comprised a mix of open ended and multiplechoice alone, and were in French. The questionnaire captured healthcare providers' demographic and hospital-related characteristics. We also queried their knowledge about EVD (definition and symptoms), training in Ebola case management, use of protective equipment, case management of conditions with primary symptoms similar to EVD (particularly fever, vomiting or diarrhea), and their care provision practices before, during, and after the EVD outbreak (including temperature measurement, ANC, immunization, and delivery). For each health district included, these periods were defined by the dates the first and last EVD cases were recorded. Information on the challenges CHWs encountered during the EVD outbreak and their opinion on population-based facility attendance (changes in service attendance, reasons for the changes) during and after the EVD outbreak were captured using the same questionnaire.

\section{Data analysis}

Study data were entered independently by two data clerks, and were compared and cleaned using Epidata software (version 3.1; EpiData Association, Odense, Denmark). Statistical analyses were performed using STATA 13 (Stata Corp, Texas, and USA). We used proportions ( $95 \%$ confidence intervals) and means \pm standard deviation (SD) to summarize the characteristics of the study population. The two-sample z-test was used to compare sample proportion across study periods.

\section{Ethical considerations}

The study protocol was approved by the scientific committee of the Department of Public Health, Faculty of Medicine, Gamal University of Conakry and the National Ethics Committee for Health Research in Guinea (N ${ }^{\circ}$. 100/CNERS/16).

\section{Results}

\section{Profile of maternal and child health care workers in ebola-affected rural Guinea}

Most of the 299 respondents were employed in health centres/posts (59.2\%), with fewer from district (25.8\%) and regional level maternities (15.1\%; Table 1). One-third of respondents $(33.4 \%)$ worked in a delivery unit, while $24.1 \%$ and $23.1 \%$ worked in antenatal care and immunization units, respectively. Nearly half of the participating CHWs were nurses/health technicians (48.5\%), followed by midwives (23.4\%), managers (16.1\%), and physicians (12.0\%). Most CHWs (68.9\%) had more than three years' experience at their current work place.

\section{Knowledge on ebola virus disease}

Most CHWs (89.3\%) reported confidence in identifying a suspected case of Ebola (Table 2). The most frequently cited individual symptoms of EVD included fever (91.3\%), vomiting/nausea $(83.9 \%)$, diarrhoea $(82.6 \%)$, bleeding $(71.2 \%)$, headache $(67.2 \%)$, and fatigue $(58.9 \%)$. The majority selected the presence of fever and two other symptoms as the most accurate case definition $(58.5 \%)$, and reported having received training on infection prevention measures $(82.6 \%)$ and the use of personal protective equipment $(87.0 \%)$ in the context of Ebola.

\section{Management of cases before, during and after the EVD outbreak}

Data on the day to day management of maternal and child health before, during, and after the EVD outbreak are presented in Table 3. Prior to the EVD outbreak, fever cases and those patients presenting with diarrhoea or vomiting were 
Table 1: Profile of CHW Providing Maternal and Child Health Services in Rural Guinea, 2015 (N=299)

\begin{tabular}{|c|c|c|}
\hline $\begin{array}{l}\text { Respondent } \\
\text { Characteristics }\end{array}$ & Number & $\begin{array}{l}\text { Percentage } \\
(95 \% \mathrm{CI})\end{array}$ \\
\hline \multicolumn{3}{|l|}{ Health facilities } \\
\hline Health centre & 177 & $59.2(53.5-64.6)$ \\
\hline District level maternity & 77 & $25.8(21.1-31.0)$ \\
\hline Regional level maternity & 45 & $15.1(11.4-19.5)$ \\
\hline \multicolumn{3}{|l|}{ Provider's working unit } \\
\hline Delivery unit & 100 & $33.4(28.3-39.0)$ \\
\hline Antenatal care unit & 72 & $24.1(19.6-29.2)$ \\
\hline Immunization unit & 69 & $23.1(18.7-28.2)$ \\
\hline Administration & 34 & $11.4(8.3-15.5)$ \\
\hline Paediatric unit & 24 & $8.0(5.5-11.7)$ \\
\hline \multicolumn{3}{|l|}{ Provider's position } \\
\hline Nurse/health technician & 145 & $48.5(42.9-54.1)$ \\
\hline Midwife & 70 & $23.4(19.0-28.5)$ \\
\hline Manager & 48 & $16.1(12.3-20.6)$ \\
\hline Physician & 36 & $12.0(8.8-16.2)$ \\
\hline \multicolumn{3}{|l|}{ Sex } \\
\hline Female & 156 & $52.2(46.5-57.8)$ \\
\hline Male & 143 & $47.8(42.2-53.5)$ \\
\hline Mean age (SD), years & & $40.8 \pm 10.6$ \\
\hline \multicolumn{3}{|l|}{$\begin{array}{l}\text { Years of experience at } \\
\text { this facility }\end{array}$} \\
\hline Less than 12 months & 21 & $7.0(4.6-10.5)$ \\
\hline Between 1 and 3 years & 72 & $24.1(19.6-29.2)$ \\
\hline More than 3 years & 206 & $68.9(63.4-73.9)$ \\
\hline
\end{tabular}

directly managed within the facility by respectively $87 \%$ and $88 \%$ of CHWs. In addition, $88 \%$ and $84 \%$ of CHWs declared that, respectively, fever or diarrhoea/vomiting did not prevent them from providing care to patients. However, a statistically significant decline was observed during the EVD outbreak where most CHWs referred cases of fever to another facility or an EVD treatment centre an only $19 \%$ of patient presenting with diarrhoea or vomiting were managed within the facility $(\mathrm{p}<0.001)$. As compared to the situation during the EVD outbreak, there were statistically significant improvements in reporting of within-facility case management after the EVD outbreak (Table 3). However, the proportion of respondents indicating that potential cases were managed within the facility after the EVD outbreak was lower than during the period before the EVD outbreak.

\section{Care-giving practices before, during and after the EVD outbreak}

Compared to the period before the EVD outbreak when approximately half of respondents $(48.5 \%)$
Table 2: Maternal and child health care provider knowledge on the Ebola Virus Disease in Guinea, 2015 $(\mathrm{N}=299)$

\begin{tabular}{|c|c|c|}
\hline Variables & Number & $\begin{array}{l}\text { Percentage } \\
(95 \% \text { CI })\end{array}$ \\
\hline \multicolumn{3}{|l|}{$\begin{array}{l}\text { Do you feel confident to } \\
\text { identify a suspected } \\
\text { case of Ebola? }\end{array}$} \\
\hline Yes & 267 & $89.3(85.3-92.3)$ \\
\hline No & 31 & $10.4(7.4-14.3)$ \\
\hline Undecided & 1 & $0.3(0.1-1.9)$ \\
\hline \multicolumn{3}{|l|}{$\begin{array}{l}\text { If "Yes", what is the } \\
\text { best case definition? }\end{array}$} \\
\hline $\begin{array}{l}\text { Fever }+2 \text { other } \\
\text { symptoms }\end{array}$ & 175 & $58.5(52.8-64.0)$ \\
\hline $\begin{array}{l}\text { Fever }+ \text { history of } \\
\text { contact with an EVD } \\
\text { case }\end{array}$ & 161 & $53.8(48.2-59.4)$ \\
\hline Bleeding & 153 & $51.2(45.5-56.8)$ \\
\hline \multicolumn{3}{|l|}{$\begin{array}{l}\text { What are the symptoms } \\
\text { of Ebola? }\end{array}$} \\
\hline Fever & 273 & $91.3(87.6-94.0)$ \\
\hline Vomiting/Nausea & 251 & $83.9(79.4-87.7)$ \\
\hline Diarrhoea & 247 & $82.6(77.9-86.5)$ \\
\hline Bleeding & 213 & $71.2(65.9-76.1)$ \\
\hline Headache & 201 & $67.2(61.7-72.3)$ \\
\hline Fatigue & 176 & $58.9(53.2-64.3)$ \\
\hline Stomach pain & 116 & $38.8(33.4-44.4)$ \\
\hline Lack of appetite & 103 & $34.4(29.3-40.0)$ \\
\hline Muscle aches & 98 & $32.8(27.7-38.3)$ \\
\hline Hiccups & 91 & $30.4(25.5-35.9)$ \\
\hline Joint pain & 85 & $28.4(23.6-33.8)$ \\
\hline Difficulty breathing & 57 & $19.1(15.0-23.9)$ \\
\hline \multicolumn{3}{|c|}{$\begin{array}{l}\text { Did you receive any } \\
\text { training on infection } \\
\text { prevention during the } \\
\text { EVD outbreak? }\end{array}$} \\
\hline Yes & 247 & $82.6(77.9-86.5)$ \\
\hline No & 51 & $17.1(13.2-21.7)$ \\
\hline Unknown & 1 & $0.3(0.1-1.9)$ \\
\hline \multicolumn{3}{|l|}{$\begin{array}{l}\text { Did you receive any } \\
\text { training on the use of } \\
\text { personal protective } \\
\text { equipment during the } \\
\text { EVD outbreak? }\end{array}$} \\
\hline Yes & 260 & $87.0(82.7-90.3)$ \\
\hline No & 38 & $12.7(9.4-17.0)$ \\
\hline Unknown & 1 & $0.3(0.1-1.9)$ \\
\hline
\end{tabular}

${ }^{a} n=267 . \quad E V D=$ Ebola virus disease. $C I=$ Confidence intervals

reported systematically measuring body temperature prior to providing care to patients, the majority (98\%) reported doing so during and after $(88 \%)$ the EVD outbreak ( $\mathrm{p}<0.001)$. Before the 
EVD outbreak, body temperature was typically measured axillary $(81.3 \%)$ whereas the majority

Table 3: Self-reported case management practices by maternal and child healthcare providers before, during and after the Ebola Virus Disease outbreak in rural Guinea $(\mathrm{N}=299)$

\begin{tabular}{|c|c|c|c|c|c|c|}
\hline \multirow[b]{2}{*}{ Variables } & \multicolumn{3}{|c|}{ Time periods } & \multicolumn{3}{|c|}{ Time periods } \\
\hline & $\begin{array}{l}\text { Before } \\
\text { n }(\%)\end{array}$ & $\begin{array}{l}\text { During } \\
\text { n }(\%)\end{array}$ & P-value & $\begin{array}{l}\text { During } \\
\text { n }(\%)\end{array}$ & $\begin{array}{l}\text { After } \\
\text { n }(\%)\end{array}$ & P-value \\
\hline \multicolumn{7}{|l|}{ Case management } \\
\hline $\begin{array}{l}\text { How did you generally behave when you } \\
\text { received a patient with fever? }\end{array}$ & & & $<0.001$ & & & 0.005 \\
\hline It was managed within the facility & $259(86.6)$ & $34(11.4)$ & & $34(11.4)$ & $111(37.1)$ & \\
\hline $\begin{array}{l}\text { Referred to another facility/EVD treatment } \\
\text { centre }\end{array}$ & $30(10.0)$ & $265(88.6)$ & & $265(88.6)$ & $188(62.9)$ & \\
\hline Undecided & $10(3.3)$ & $0(0.0)$ & & $0(0.0)$ & $0(0.0)$ & \\
\hline $\begin{array}{l}\text { Did fever generally prevent you from } \\
\text { providing care to a patient? }\end{array}$ & & & $<0.001$ & & & 0.005 \\
\hline Yes & $34(11.4)$ & $147(49.2)$ & & $147(49.2)$ & $67(22.4)$ & \\
\hline No & $262(87.6)$ & $151(50.5)$ & & $151(50.5)$ & $196(65.6)$ & \\
\hline Undecided & $3(1.0)$ & $1(0.3)$ & & $1(0.3)$ & $36(12.0)$ & \\
\hline $\begin{array}{l}\text { How did you generally behave when you } \\
\text { received a patient with diarrhoea or } \\
\text { vomiting? }\end{array}$ & & & $<0.001$ & & & 0.003 \\
\hline Managed within the facility & $262(87.6)$ & $57(19.1)$ & & $57(19.1)$ & $124(41.5)$ & \\
\hline Referred to another facility & $31(10.4)$ & $242(80.9)$ & & $242(80.9)$ & $175(58.5)$ & \\
\hline Undecided & $6(2.0)$ & $0(0.0)$ & & $0(0.0)$ & $0(0.0)$ & \\
\hline $\begin{array}{l}\text { Did diarrhoea or vomiting generally } \\
\text { prevent you from providing care to a } \\
\text { patient? }\end{array}$ & & & $<0.001$ & & & 0.001 \\
\hline Yes & $46(15.4)$ & $164(54.8)$ & & $164(54.8)$ & 85 (28.4) & \\
\hline No & $250(83.6)$ & $105(35.1)$ & & $105(35.1)$ & $166(55.5)$ & \\
\hline Undecided & $3(1.0)$ & $30(10.0)$ & & $30(10.0)$ & $48(16.1)$ & \\
\hline \multicolumn{7}{|l|}{ Care giving practices } \\
\hline Systematically measured body temperature & & & $<0.001$ & & & $<0.001$ \\
\hline Always & $145(48.5)$ & $294(98.3)$ & & $294(98.3)$ & $263(88.0)$ & \\
\hline Sometimes & $90(30.1)$ & $3(1.0)$ & & $3(1.0)$ & $8(2.7)$ & \\
\hline Never & $64(21.4)$ & $1(0.3)$ & & $1(0.3)$ & $0(0.0)$ & \\
\hline Undecided & $0(0.0)$ & $1(0.3)$ & & $1(0.3)$ & $28(9.4)$ & \\
\hline $\begin{array}{l}\text { How was body temperature generally } \\
\text { measured }\end{array}$ & & & $<0.001$ & & & 0.001 \\
\hline Axillary & $243(81.3)$ & $11(3.7)$ & & $11(3.7)$ & $10(3.3)$ & \\
\hline Anal & $5(1.7)$ & $2(0.7)$ & & $2(0.7)$ & $0(0.0)$ & \\
\hline Buccal & $0(0.0)$ & $0(0.0)$ & & $0(0.0)$ & $0(0.0)$ & \\
\hline Thermo flash & $0(0.0)$ & $284(95.0)$ & & $284(95.0)$ & $261(87.3)$ & \\
\hline Undecided & $51(17.1)$ & $2(0.7)$ & & $2(0.7)$ & $0(0.0)$ & \\
\hline \multicolumn{7}{|c|}{$\begin{array}{l}\text { Systematically wore gloves when measuring } \\
\text { temperature }\end{array}$} \\
\hline Always & $79(26.4)$ & $282(94.3)$ & $<0.001$ & $282(94.3)$ & $255(85.3)$ & 0.001 \\
\hline Sometimes & $64(21.4)$ & $9(3.0)$ & & $9(3.0)$ & $13(4.3)$ & \\
\hline Never & $116(38.8)$ & $6(2.0)$ & & $6(2.0)$ & $1(0.3)$ & \\
\hline Undecided & $40(13.4)$ & $2(0.7)$ & & $2(0.7)$ & $30(10.0)$ & \\
\hline $\begin{array}{l}\text { Protective equipment systematically used } \\
\text { during ANC and immunization care }\end{array}$ & & & $<0.001$ & & & 0.004 \\
\hline Gloves & $213(71.2)$ & $259(86.6)$ & & $259(86.6)$ & $229(76.6)$ & \\
\hline Gowns & $233(77.9)$ & $237(79.3)$ & & $237(79.3)$ & $223(74.6)$ & \\
\hline Glasses & $47(15.7)$ & $148(49.5)$ & & $148(49.5)$ & $121(40.5)$ & \\
\hline Helmet & 34 (11.4) & $142(47.5)$ & & $142(47.5)$ & $92(30.8)$ & \\
\hline Boots & $29(9.7)$ & $130(43.5)$ & & $130(43.5)$ & $95(31.8)$ & \\
\hline Face screen plastic & $11(3.7)$ & $120(40.1)$ & & $120(40.1)$ & $89(29.2)$ & \\
\hline Protective equipment used systemaically & & & 0.023 & & & 0.001 \\
\hline
\end{tabular}




\begin{tabular}{lllll}
\hline during delivery & & & & \\
Gloves & $279(93.3)$ & $291(97.3)$ & $291(97.3)$ & $272(91.0)$ \\
Gowns & $249(83.3)$ & $257(86.0)$ & $257(86.0)$ & $231(77.3)$ \\
Boots & $118(39.5)$ & $228(76.3)$ & $228(76.3)$ & $191(63.9)$ \\
Glasses & $124(41.5)$ & $224(74.9)$ & $224(74.9)$ & $184(61.5)$ \\
Helmet & $62(20.7)$ & $205(68.6)$ & $205(68.6)$ & $172(57.5)$ \\
Plastic face screen & $36(12.0)$ & $179(59.9)$ & $179(59.9)$ & $150(50.2)$ \\
$\begin{array}{l}\text { Challenges in providing maternal and child } \\
\text { health services during the EVD outbreak }\end{array}$ & & & & \\
No challenges & N.A & $14(4.7)$ & $14(4.7)$ & N.A \\
Difficulty in screening for Ebola cases & N.A & $273(91.3)$ & $273(91.3)$ & N.A \\
Lack of relevant equipment & N.A & $130(43.5)$ & $130(43.5)$ & N.A \\
Drugs/vaccines stock out & N.A & $8(2.7)$ & $8(2.7)$ & N.A \\
Lack of skilled staff & N.A & $2(0.7)$ & $2(0.7)$ & N.A \\
\hline
\end{tabular}

$E V D=$ Ebola virus disease. $A N C=$ Antenatal care. $N . A=$ Not applicable .

Table 4: Self-reported opinion of providers on maternal and child health service attendance during and after the Ebola virus disease outbreak in Guinea, $2015(\mathrm{~N}=299)$

\begin{tabular}{|c|c|c|c|}
\hline Variables & During & After & P-value \\
\hline \multicolumn{4}{|l|}{$\begin{array}{l}\text { Changes observed in the use of maternal and child health } \\
\text { services since the onset of the EVD }\end{array}$} \\
\hline Increase & $13(4.3)$ & $215(71.9)$ & $<0.001$ \\
\hline Decrease & $272(91.0)$ & $27(9.0)$ & \\
\hline No change & $8(2.7)$ & $19(6.4)$ & \\
\hline Undecided & $6(2.0)$ & $38(12.7)$ & \\
\hline \multicolumn{4}{|l|}{$\begin{array}{l}\text { If decrease in use of services after the onset of EVD, what are the } \\
\text { reasons? }(\mathrm{N}=272)\end{array}$} \\
\hline Lack of trust of users with providers & $269(98.9)$ & NA & \\
\hline Fear of contamination in health facilities & $247(90.8)$ & NA & \\
\hline Fear of being sent into an EVD treatment centre & $225(82.7)$ & NA & \\
\hline Other reasons* & $148(54.4)$ & NA & \\
\hline The facility was momentarily closed & $23(8.5)$ & NA & \\
\hline \multicolumn{4}{|l|}{$\begin{array}{l}\text { If increase in use of services after the EVD outbreak ended, how } \\
\text { do you explain this? }(\mathrm{N}=\mathbf{2 1 5})\end{array}$} \\
\hline Fear of contamination in health facilities has disappeared & N.A & $166(77.2)$ & \\
\hline Fear of being sent into an EVD treatment centre has disappeared & N.A & $126(58.6)$ & \\
\hline Return of trust of users with providers & N.A & $112(52.1)$ & \\
\hline Others** & N.A & $61(28.8)$ & \\
\hline Facilities reopening & N.A & $12(5.6)$ & \\
\hline
\end{tabular}

*Deadly virus, no treatment, rumours about EVD

**Stigmatisation of EVD patients, certainty to recover from EVD

$E V D=$ Ebola virus disease. N.A = Not applicable.

used an electronic flash thermometer during $(95.0 \%)$ and after the EVD outbreak $(87.3 \%$; $\mathrm{p}<0.001)$. The systematic use of gloves during ANC and immunization care increased from $71.2 \%$ before the EVD outbreak to $86.6 \%$ during $(\mathrm{p}<0.001)$ but significantly decreased $(76.6 \%)$ after the EVD outbreak ended $(\mathrm{p}=0.001)$. Similar trends across these periods were observed in the use of gowns during ANC and immunization care (77.9\% before vs. $79.3 \%$ during and $74.6 \%$ after, $\mathrm{p}=\mathrm{X})$. The use of gloves and gowns during delivery significantly increased during the EVD outbreak as compared to the period before the EVD outbreak $(p=0.023)$ but decreased in the period after the EVD outbreak compared to the EVD outbreak ( $\mathrm{p}=0.001)$.

The challenges raised by CHWs regarding the provision of maternal and child health services during the EVD outbreak included: difficulty in screening for EVD cases within the facility (91.3\%), lack of relevant equipment (43.5\%), drug and vaccine stock-outs within the facility $(2.7 \%)$, and the lack of skilled staff $(0.7 \%)$. 
Opinion on maternal and child health service attendance during and after the EVD outbreak

The majority of CHWs (91\%) reported a decrease in the use of $\mathrm{MCH}$ services during the EVD outbreak, but $72 \%$ reported an increase in the period after the EVD outbreak (Table 4). The change in services use after the EVD outbreak as compared to the period before the EVD outbreak was statistically significant $(p<0.001)$.

The main reasons for the reported decrease in service use during the EVD outbreak were lack of user trust in health care providers (98.9\%), fear of EVD infection at health facilities (90.8\%), fear of being sent to an EVD treatment centre $(82.7 \%)$, and partial closure of the health facility $(8.5 \%)$. More than half of CHWs reported other related reasons for decrease in service use including the high case-fatality rate of the virus, the non-existence of EVD treatment and other rumours about EVD. As for the increase in the use of services reported after the EVD outbreak, many CHWs said it was due to the decrease of fear of infacility infections or referral to EVD treatment centres within the community $(77.2 \%$ and $58.6 \%$, respectively), or to the return of trust in providers (52.1\%). Few CHWs (5.6\%) reported that the use of services improved because of the reopening of health facilities that closed during the EVD outbreak.

\section{Discussion}

The findings of our study on maternal and child health services delivery before, during and after the Ebola virus disease outbreak in Guinea revealed differences in provider-reported practices and case management across these three periods. The study is the first of its kind in Guinea and has important implications for preparedness and management of future epidemics in similar contexts.

Overall, our results suggested that most rural CHWs had received training in infection prevention and use of personal protective equipment during the Ebola outbreak, and expressed high levels of confidence in the identification of possible EVD cases. However, CHWs reported significant alterations to their normal care-giving practices with the onset of the epidemic as they had limited ability to properly screen for EVD during the outbreak.

Ebola diagnosis in rural health facilities was impossible during much of the outbreak; diagnosis of EVD was laboratory-based and required detection of the virus by polymerase chain reaction (PCR), a technology not available at the peripheral health care level. Through the end of the epidemic, no rapid diagnosis test of EVD was available to help differentiate cases with similar symptoms. This unavailability of a reliable diagnostic test in the presence of unspecific but Ebola-related symptoms led to quasi-systematic referral of possible cases by CHWs. This practice may have contributed to worsening the mistrust between users and providers.

Because maternal and child health services carry greater than average infection risk ${ }^{11}$, CHWs may have more frequently decided to simply refer patients with potential EVD symptoms for fear of hospital contamination. These referrals were likely motivated by the increase of EVD cases in CHWs that was observed across the country during the outbreak $^{12,13}$. In addition, Barry et al. ${ }^{14}$ reported that $72 \%$ of acute EVD patients in Conakry presented with malaria comorbidity, further complicating differentiating initial EVD symptoms to those of malaria and childhood respiratory tract infection $^{14}$. As a result, many non-Ebola cases ended up referred as well. This practice may have discouraged the population from seeking care in health facilities, leading to the decrease in the use of health services reported in West Africa, especially for maternal and child health services ${ }^{15-}$ 18. It may have also created or maintained mistrust and reluctance of the population with health care providers as the latter would be accused of sending patients to Ebola treatment centres against their will ${ }^{5}$.

Fortunately, the unintended consequences of these liberal referral practices may be mitigated in future epidemics due to technological innovation. Only recently, promising results of a rapid EVD diagnostic test (RDT) evaluated in Guinea have been published ${ }^{19}$. If approved, the availability of a RDT at rural health facilities would considerably facilitate the screening of 
suspected patients in maternal and child health services and reduce unnecessary referrals.

Our results show that infection prevention measures have improved in maternal and child health services because of training efforts deployed by all stakeholders for the control of EVD. Systematic use of gloves and measurement of body temperature improved during and after the EVD outbreak as compared to the period before. However, these efforts were reduced in the period after the EVD outbreak, calling for more followup to maintain the gains obtained during the EVD outbreak and at least achieve the level of indicators that existed before the EVD outbreak. Our results are higher than those reported by Toure et al. (2016) ${ }^{4}$ in their study of CHWs in Conakry where the use of gloves was not systematic for the majority of CHWs (up to 90\%). The discrepancy in results may be due to the studies being done at different points of time. Toure et al's study ${ }^{4}$ was conducted early in the EVD outbreak, prior to large scale implementation of training and infection prevention and control (IPC) measures. With time, more efforts were put in place by the Guinean authorities and other stakeholders to integrate international IPC guidelines, build provider capacity and supply health facilities with prevention kits, especially in areas where the incidence of EVD was high ${ }^{20}$. A study in Sierra Leone reported that after the implementation of new infection prevention and control measures such as a triage system, EVD cases in CHWs declined rapidly ${ }^{21}$. In Liberia, the establishment of a national IPC task force under the leadership of the Ministry of Health allowed the standardization of IPC messaging and training of CHWs, leading to the successful containment of the outbreak ${ }^{22}$.

HCWs reported a decrease in the use of services during the EVD but an increase after the EVD in their facilities. The negative impact of the EVD on health services utilization, especially on maternal and child health services has been documented in Liberia and Sierra Leone ${ }^{15-18}$. In addition, Thiam et al. $(2015)^{5}$ reported that additional factors such as "inadequate communication strategy, misconceptions around the disease, ignorance of local culture and customs and lack of involvement of local communities in the control strategies", have maintained and reinforced the mistrust and reluctance of

communities to engage in EVD control activities. After the end of the EVD in their areas, HCWs noted improvements in the use of most maternal and child health services. However, some of the reported behaviours were lower in the postEVD period compared to the EVD period. This is concerning as maintenance of infection control measures is necessary for maintaining high quality care and for rapidly stemming future outbreaks. It is therefore important to maintain the gains from the IPC measures implemented during the EVD outbreak as it might also benefit other infections, resulting in CHWs and their patients being protected not only from EVD but also from other nosocomial and blood transmitted infections such as HIV in hospital settings.

Nearly three quarters of our respondents were nurses/health technicians and midwives, cadres who were at the forefront of maternal and child health provision in rural Guinea during the EVD outbreak. At the time of interview, most CHWs reported working in the same location as they had both before and during the EVD outbreak. However, the number of CHWs in our study areas was low as compared to the rest of the country. The two regions together accounted for $30 \%$ of the country's population but had only $16 \%$ of the nationwide human resources for health ${ }^{7,9}$. This underscores the need to focus on meeting the need for rural human resources for health, a challenge not unique to Guinea, but critical for optimizing population health and preventing future epidemics.

\section{Limitations}

The study has several limitations. Data rely on information provided retrospectively by CHWs through a self-reported questionnaire after the end of the EVD outbreak. Information about practices and attitudes were not directly observed; therefore, they could have been over- or underreported by CHWs or otherwise subject to bias. As our study sample was captured after the EVD outbreak, our participants were limited to those CHWs who survived. We were unable to interview service 
users and contrast their views with that of the CHWs.

\section{Conclusion}

Our study shows that knowledge of optimal practices for EVD prevention and case management among maternal and child health workforce in rural Guinea differed substantially before, during and after the Ebola outbreak. Infection prevention and control measures established during the EVD outbreak substantially improved self-reported provider practices. However, more efforts are needed to maintain and sustain the gain achieved to optimize health outcomes moving forward.

\section{References}

1. Ebola virus disease (EVD) in West Africa: an extraordinary epidemic. Wkly Epidemiol Rec 2015; 90(10):89-96.

2. WHO. Ebola response roadmap - Situation report, 2016 ; accessed 17 March 2016. Available at: http://apps.who.int/ebola/current-situation/ebolasituation-report-16-march-2016

3. Coordination Nationale Ebola, Guinée and OMS. Rapport de la Situation Epidémiologique, Maladie à Virus Ebola en Guinée du 14 Février 2016. Sit_Rep_no 670. Conakry: Coordination Ebola, Guinée, OMS 2016; Available at: http://guineaebov.github.io/

4. Toure A, Traore FA, Sako FB, Delamou A, Tonguino FS, Sylla D, Bagoura M, Barry M, Cisse M, Vanhems P. Knowledge, attitudes, and practices of health care workers on Ebola virus disease in Conakry, Guinea: A cross-sectional study. academicJournal, 2016; 8(2), pp. 12-16.

5. Thiam S, Delamou A, Camara S, Carter J, Lama EK, Ndiaye B, Nyagero J, Nduba J, Ngom M. Challenges in controlling the Ebola outbreak in two prefectures in Guinea: why did communities continue to resist? Pan Afr Med J, 2015; 2015 Oct $11 ; 22$.

6. Oladimeji AM, Gidado S, Nguku P, Nwangwu IG, Patil ND, Oladosu F, Roberts AA, Waziri NE, Shuaib F, Oguntimehin O, Musa E, Nasidi A, Adewuyi P, Olayinka A, Odubanjo O; N-FELTP Residents, Poggensee G. Ebola virus disease - gaps in knowledge and practice among healthcare workers in Lagos, August 2014. Trop Med Int Health, 2015; 20(9):1162-1170.

7. Présidence de la République de Guinée. Troisième recensement général de la population et de l'habitat

2014. Décret D/2015/225/PRG/SGG. Conakry, Guinée : Institut National des Statistiques, 2015.
8. Institut National des Statistiques G. Enquête Démographique et de Santé et à Indicateurs Multiples, Guinée 2012. Claverton, Maryland, USA : INS \& Macro, 2014.

9. Ministère de la Santé. Plan national de développement sanitaire 2015-2024. Conakry, République de Guinée : Ministère de la santé, 2015.

10. Centers for Disease Control and Prevention. Preparing Healthcare Workers to Work in Ebola Treatment Units (ETUs) in Africa, 2015; accessed 15 March 2016. Available at: http://www.cdc.gov/vhf/ebola/hcp/safety-trainingcourse/

11. Delamou A, Hammonds RM, Caluwaerts S, Utz B, Delvaux T. Ebola in Africa: beyond epidemics, reproductive health in crisis. Lancet, 2014 ; 384(9960) : 2015.

12. Evans DK, Goldstein M, Popova A. Health-care worker mortality and the legacy of the Ebola epidemic. Lancet Glob Health, 2015 3(8): e439-40.4.

13. Delamou A, Beavogui AH, Kondé MK, van Griensven J, De Brouwere V. Ebola: better protection needed for Guinean health-care workers. Lancet, 2015; 7;385(9967):503-4.

14. Barry M, Traoré FA, Sako FB, Kpamy DO, Bah EI, Poncin M, et al. Ebola outbreak in Conakry, Guinea: epidemiological, clinical, and outcome features. Med Mal Infect, 2014; 44(11-12):491-4.

15. Plucinski MM, Guilavogui T, Sidikiba S, Diakité N, Diakité S, Dioubaté M, Bah I, Hennessee I, Butts JK, Halsey ES, McElroy PD, Kachur SP, Aboulhab J, James R, Keita M. Effect of the Ebola-virusdisease epidemic on malaria case management in Guinea, 2014: a cross-sectional survey of health facilities. Lancet Infect Dis, 2015; 15(9):1017-23.

16. Barden-O'Fallon J, Barry MA, Brodish P, Hazerjian J. Rapid Assessment of Ebola-Related Implications for Reproductive, Maternal, Newborn and Child Health Service Delivery and Utilization in Guinea. PLoS Curr. 2015; 4;7. pii: ecurrents.outbreaks.

17. Lori JR, Rominski SD, Perosky JE, Munro ML, Williams G, Bell SA, Nyanplu AB, Amarah PN, Boyd CJ. A case series study on the effect of Ebola on facility-based deliveries in rural Liberia. BMC Pregnancy Childbirth, 2015. 12; 15:254.

18. Brolin Ribacke KJ, van Duinen AJ, Nordenstedt H, Höijer J, Molnes R, Froseth TW, Koroma AP, Darj E, Bolkan HA, Ekström A.. The Impact of the West Africa Ebola Outbreak on Obstetric Health Care in Sierra Leone. PLoS One, 2016; 24;11(2): e0150080.

19. Kurosaki Y, Magassouba N, Oloniniyi OK, Cherif MS, Sakabe S, Takada A, Hirayama K, Yasuda J. Development and Evaluation of Reverse Transcription-Loop-Mediated Isothermal Amplification (RT-LAMP) Assay Coupled with a Portable Device for Rapid Diagnosis of Ebola Virus Disease in Guinea. PLoS Negl Trop Dis, 2016; 22;10(2): e0004472.

20. WHO. Hand hygiene in health care in the context of 
Delamou et al.

Filovirus disease outbreak response Rapid advice guideline, 2014; accessed 29 May 2016. Available at:

http://www.who.int/csr/resources/publications/ebola /hand-hygiene/en/

21. Senga M, Pringle K, Ramsay A, Brett-Major DM,

Fowler RA, French I, Vandi M, Sellu J, Pratt C, Saidu J, Shindo N, Bausch DG; Sierra Leone
Reproductive Healthcare Workers and Ebola

Kenema District Task Force and Kenema Government Hospital. Factors Underlying Ebola Virus Infection Among Health Workers, Kenema, Sierra Leone, 2014-2015. Clin Infect Dis. 2016 Aug 15;63(4):454-9

22. Cooper C, Fisher D, Gupta N, MaCauley R, Pessoa-Silva CL. Infection prevention and control of the Ebola outbreak in Liberia, 2014-2015: key challenges and successes. BMC Med, 2016; 5;14:2. doi: 10.1186/s12916-015-0548-4. 